\title{
O SISTEMA ECONÔMICO BRASILEIRO E A DOSAGEM DOS TRIBUTOS
}

\author{
Milena Zampieri Sellmann ${ }^{1}$ \\ Paulo Pereira Leite Filho
}

\section{Resumo:}

O ponto central do trabalho é a análise do modelo do Estado desenhado pela Constituição, passando pelo sistema econômico brasileiro e a dosagem dos tributos. Para tanto, serão estudados o modelo econômico, o grau de intervenção do Estado na sociedade, a dimensão do poder público e as garantias específicas do contribuinte. A partir desses parâmetros, construirse-á uma equação que permita uma tributação que satisfaça as decisões políticas estatais, sem sufocar os contribuintes.

Palavras-chave: Estado. Sistema econômico. Tributação. Garantias. Dosagem.

\section{THE BRAZILIAN ECONOMIC SYSTEM AND THE DOSAGE OF TAXES}

\begin{abstract}
:
The central point of the work is the analysis of the State model designed by the Constitution, passing through the Brazilian economic system and the dosage of taxes. To this end, the economic model, the degree of State intervention in society, the size of public power and the specific guarantees of the taxpayer will be studied. From these parameters, an equation will be constructed that allows a taxation that satisfies the state political decisions, without suffocating the taxpayers.
\end{abstract}

Keywords: State. Economic system. Taxation. Guarantees. Dosage.

\footnotetext{
${ }^{1}$ Especialista, Mestre e Doutora em Direito Tributário pela PUC/SP. MBA na área de gestão universitária. Extensão Universitária em Boston College, Laspau, University of Toronto, University of London, University of Southern California, Hong kong Institute of Education, Center for World-Class Universities of Shanghai Jiao Tong University e Université Paris - Est Créteil. Graduada em Direito pelo Centro Universitário Salesiano de São Paulo - U. E. de Lorena/SP. Advogada tributarista, preventiva e contenciosa, desde 2000. Professora de Direito Tributário nos Cursos de Graduação e Pós-graduação (lato sensu e stricto sensu) em Direito do Centro Universitário Salesiano de São Paulo - U. E. de Lorena/SP, instituição na qual também atuou como Coordenadora do Curso de Direito. Professora de Direito Tributário e Prática Tributária no Damásio Educacional. milenasellmann @ hotmail.com.

${ }^{2}$ Possui graduação em Direito pela Universidade de São Paulo (1988). Atualmente é professor de direito da Universidade Estácio de Sá e juiz federal de primeiro grau - Tribunal Regional da 2ª Região. pplf1 @ hotmail.com
} 


\section{INTRODUÇÃO}

Muito se tem questionado acerca da intensidade da carga tributária que recai, direta ou indiretamente, sobre a sociedade, em especial nos momentos de crise econômica, que impulsiona, a largos passos, o empobrecimento, com perda de receitas e liquidação de patrimônio, não raro apenas para a manutenção da sobrevivência, como é o caso, por exemplo, dos inúmeros desempregados. A par de diversas explicações econômicas, imbricadas com outras tantas de natureza política, a questão que ora se põe em evidência é a dose da tributação.

De um lado, preconiza-se aliviar a tributação, porquanto seus efeitos gerariam, $a$ priori, o fomento da economia, na medida em que parcela da riqueza retida no campo privado teria o condão de otimizar o consumo e, por consequência, toda a cadeia produtiva para abastecê-lo. Lado outro, o alívio da tributação representaria a diminuição de transferência de riqueza para o setor público, que compete, por sua vez, prover as ações sociais afirmativas, suprindo as carências dos seguimentos sociais desfavorecidos. A contradição se estabelece. $\mathrm{Ou}$ se arrecada mais e, provido, cumpre-se com as prestações sociais, ou se arrecada menos, mas em algum momento faltará provisão bastante para cumprir aquele desiderato, ainda que sob a esperança de que o crescimento econômico gerará, paulatinamente, o aumento da arrecadação, dês que então haverá um maior número razões tributáveis. Não se perca de vista, entretanto, que o deficit social já instalado desafia medidas imediatas, não resistindo à chegada da prosperidade futura e incerta ${ }^{3}$. Chega a ser curioso que no mesmo veículo de mídia se possa constatar enorme oscilação entre posições diametralmente opostas, ora se propondo o incremento das políticas públicas assistenciais, o que desafia aumento receitas, ora se defendendo a diminuição da carga tributária, a resultar em diminuição de receitas. Quase uma aporia.

O presente arrazoado não pretende definir em números a tributação adequada ou justa. Nem poderia ter essa pretensão, aliás. Entrementes, espera-se demonstrar os parâmetros para a obtenção da melhor fixação, tomando-se em conta, inclusive, que a economia, lastro da tributação, assim como a própria sociedade, não é estática; de revés, está sempre em

\footnotetext{
${ }^{3}$ Segundo o Portal da Saúde, do Ministério da Saúde, o software SISREG (Sistema Nacional de Regulação), preliminarmente identificou 800.559 cirurgias eletivas aguardando a realização, atualizado em 3.5.17. In portaldasaúde.saude.gov.br/index.php/o-ministerio/principal/secretarias/sas/sas-noticiais/28256-sus-fila-únicapara-cirurgias-eletivas. Acesso em 10.7.2017, às 21h10.
}

Rev. de Direito, Economia e Desenvolvimento Sustentável| e-ISSN: 2526-0057| Maranhão | v. 3 | n. 2 | p. 100 - 118 | Jul/Dez. 2017. 
movimento, com avanços e retrocessos, calmarias e ebulições, desafiando, por via de consequência, ajustes perenais incidentes na tributação.

Com efeito, o primeiro passo a ser dado está na definição e assunção do regime econômico a ser adotado. A sociedade em geral trata o Brasil com um país capitalista, como de fato o é, mas há sempre segmentos que dão a entender, ou forçam o entendimento, de que o capitalismo seria mera passagem que deva ser, por ora, suportada, sem precisão temporal e, pior, sem definição de qual seria o regime porvir. A indefinição em nada contribui.

O passo subsequente é o desdobramento natural do primeiro: com qual intensidade o Estado pode, ou deve intervir na esfera privada, social e individual. É fundamental estabelecer regras precisas - e interpretações coerentes que sigam um padrão lógico -, notadamente para conferir segurança jurídica àqueles nacionais e estrangeiros que pretendam aqui investir.

A terceira etapa desafia a análise da real dimensão do Poder Público. Primeiro, mister se faz inventariar a Administração, é dizer, identificar o que já é Administração (por estranho que tal soe) e qual a dimensão de seus gastos e, ainda, qual o tamanho exato de sua dívida. Afinal, o que já está posto há de ser honrado, já que a alternativa seria a moratória, solução que não subsiste na ordem jurídica, além de demonstrar um desastre no campo econômico. O Direito Financeiro cuida do orçamento e são os tributos a maior fonte de receitas, fator preponderante, com larga margem, para o equilíbrio com as despesas. Mas não é só. Identificado o passivo, ainda haverá a definição dos investimentos (infraestrutura, modernização da máquina administrativa, etc.) e das prestações positivas (as ações estatais que irão conferir dignidade àqueles que de alguma forma se encontram segregados de um contexto social aceitável, os ditos excluídos). Nesse passo, exsurge ainda um fator que dificulta a tarefa, qual seja, a forma federativa do Estado brasileiro.

Mas a carga tributária não pode se voltar, exclusivamente, aos interesses do Poder Público e seu equilíbrio orçamentário, porquanto isso levaria a um verdadeiro massacre ao cidadão. Emergem daí dois princípios que balizam a proteção do contribuinte frente à agressividade natural da atividade fiscal, quais sejam: o princípio do não confisco e o princípio da capacidade contributiva.

Bem delineados esses parâmetros, talvez seja possível se chegar a uma tributação bem dosada, que mantenha a Administração Pública abastecida para cumprir os fins do Estado (CF, art. $3^{\circ}$ ), sem sufocar, de outra sorte, a sociedade.

Rev. de Direito, Economia e Desenvolvimento Sustentável| e-ISSN: 2526-0057| Maranhão | v. 3 | n. 2 | p. 100 - 118 | Jul/Dez. 
Daí a razão deste estudo: esmiuçar os parâmetros fornecidos pelo Direito com o propósito de construir um mecanismo eficaz e, ao mesmo tempo, pacificador, prestigiando-se o Estado Democrático de Direito, que reivindica a preservação da segurança jurídica. De verse que, a sobrevivência da democracia, regime por nós adotado, depende da observância rigorosa da ordem jurídica posta, sob pena de se conviver sob um regime patológico apenas rotulado de democrático. A metodologia empregada consiste, basicamente, em uma pesquisa embasada no referencial teórico e jurisprudencial. Orienta-se, na pesquisa bibliográfica, a partir do levantamento de referências teóricas já analisadas, publicadas por meios escritos e eletrônicos, como livros, artigos científicos em revistas, páginas de web sites, além da análise de legislação relativa à temática.

\section{OS PARÂMETROS ELEITOS}

A dosagem da tributação não entrega um valor numérico pronto e acabado. Estabelece pontos a serem desenvolvidos para a construção dessa atividade fundamental. Sim, fundamental: hoje é imprescindível à sociedade viver sob o manto de uma figura estatal, que, por sua vez reclama a existência de uma Administração Pública eficiente. E este aparato construído sobre uma plataforma jurídica irá se projetar por diversas formas materiais, todas onerosas (sedes, burocracia, viaturas, funcionários, etc.). A arquitetura do Estado e sua Administração são, portanto, moldes fundamentais para se estabelecer um modelo de arrecadação. Opções, portanto, haverão de ser realizadas pela sociedade, de sorte a se construir uma fórmula e, a partir dela, estimar as receitas necessárias, com enfoque na tributação pelo seu grau de importância, para fazer frente às despesas eleitas.

\subsection{O Sistema Econômico Brasileiro}

Não obstante o constituinte de 1988, ao contemplar os primados da livre iniciativa e da propriedade privada, tenha efetivamente eleito o sistema capitalista como modelo econômico brasileiro, acabou, a um só tempo, por construir uma plataforma jurídica um tanto quanto imprecisa ou, pelo menos, que dá margem, constantemente, a novos questionamentos ou interpretações. A todo instante, os intérpretes aparentam um certo acanhamento de externar com clareza o modelo capitalista, talvez pelo receio de receber a pecha do significado pejorativo da “direita”, associado, não raro, ao período ditatorial (1964-1985) ou, ainda, aos movimentos

Rev. de Direito, Economia e Desenvolvimento Sustentável| e-ISSN: 2526-0057| Maranhão | v. 3 | n. 2 | p. 100 - 118 | Jul/Dez. 
emblemáticos da Segunda Guerra que compuseram o Eixo (nazismo e fascismo). Falta-lhes um discurso mais preciso quanto aos princípios do sistema econômico e uma visão contemporânea do Estado Liberal ${ }^{4}$. De qualquer modo, fez-se questão também abraçar ícones próprios do sistema socialista, de modo a não estabilizar o sistema adotado. A nossa Constituição é, pois, compromissória à luz da ideologia (ou heterodoxa, ou eclética, ou pluralista, são as nomenclaturas comuns para designar esta classificação), porquanto inspirada em duas ou mais vertentes ideológicas ${ }^{5}$, quiçá numa tentativa de pacificar seguimentos historicamente conflitantes ${ }^{6}$. Afinal:

Não há grande dicotomia, no âmbito das ciências sociais, em que o liberalismo e o socialismo não se coloquem o primeiro de um lado e o segundo de outro, ou, melhor dizendo, se o primeiro se coloca de um lado, o segundo parece que não pode deixar de se colocar do outro: primado da esfera privada ou primado da esfera pública; propriedade individual ou propriedade coletiva; burguesia como sujeito histórico dominante ou proletariado como sujeito histórico alternativo; direita ou esquerda, visão individualista do homem ou visão organicista da sociedade; atomismo ou holismo; sociedade ou comunidade, e quem quiser pode acrescentar outras (BOBBIO, 2000, p.356).

A ideia de uma Constituição compromissória talvez seja amalgamar os opostos, pois somá-los linearmente seria mesmo impossível. "Comunismo e individualismo são

\footnotetext{
${ }^{4}$ Merece destaque o seguinte excerto sobre a propriedade privada: "A Propriedade Privada surge como garantia individual no inciso XXII do art. $5^{\circ}$ do texto constitucional. Sua menção no art. 170, visa a garantir que a Ordem Econômica repouse sobre aquele instituto, ou, ainda, que os fins da última (justiça social e existência digna) realizar-se-ão por meio da Propriedade Privada, que fica vinculada àquele fim. Assim razão daí a crítica de Leopoldino da Fonseca, para quem melhor seria mencionar o instituto da Propriedade Privada como fundamento da própria Ordem Econômica. Afinal, a Propriedade Privada revela-se não como algo a ser tolerado pelo Estado, mas com um Princípio de sua Ordem Econômica. Enquanto tal, deve ser fomentada pelo próprio Estado. Vê-se, daí, mais uma atuação positiva do Estado, marcada pela promoção e incentivo à Propriedade Privada (SCHOUERI, Luiz Eduardo. Direito tributário. 4. Ed. São Paulo: Saraiva, 2015, p. 356.).

${ }^{5}$ Cunha Júnior define assim este modelo: "Já a constituição eclética, ou pluralista, é aquela que logra contemplar, plural e democraticamente, várias ideologias aparentemente contrapostas, conciliando ideias que permearam as discussões na Assembleia Constituinte" (CUNHA JÚNIOR, Dirley da. Curso de direito constitucional. 5. ed. Ampl. e Atual. Salvador: Podium, 2011, p. 125).

Agra traz o seguinte conceito: "Constituição compromissória - É a constituição que se originou de um compromisso constitucional, fruto de uma ampla composição entre várias classes sociais. Em uma sociedade pósmoderna, caracterizada pela perda das metanarrativas e pela pluralidade e complexidade da sociedade, a feitura de nova Carta Magna sempre tem que resultar em uma composição das forças sociais, chegando-se a ponto de concordância mesmo em assuntos que acarretem grande conflito na sociedade" (In AGRA, Walber de Moura. Curso de direitos constitucional. 8. Ed. Rio de Janeiro: Forense, 2011, p. 62).

6 Diz-se uma "tentativa" de pacificação. Vale destacar a passagem de Carvalho: "Por isso, o confronto de socialistas e liberais não opõe ideologia a ideologia: a defesa do socialismo é sempre a autoatribuição ideológica dos méritos imaginários de um futuro possível; a do capitalismo é sempre a análise científica de processos econômicos existentes e dos meios objetivos de aumentar sua eficiência" (CARVALHO, Olavo de. O mínimo que você precisa saber para não ser um idiota. 13. Ed. Rio de Janeiro: Record, 2004, p. 129).
} 
indispensáveis: o único problema é definir na sociedade atual aquilo que deve ser comum e aquilo que deve pertencer ao indivíduo" (BOBBIO, 2000, p. 360). De fato. Eis o primeiro paradigma: o atingimento de uma fórmula que assentasse de modo perene os anseios ideológicos das diversas correntes enfeixadas em direta (capitalistas, neoliberais, etc.) e esquerda (socialistas, progressistas, etc.) ou delas decorrentes (terceira via, por exemplo). O problema que as questões ideológicas vão muito além do universo racional. São dogmáticas e, com tal, não toleram questionamentos acerca de seus alicerces adrede fixados, e, às vezes, transbordam para um radicalismo, ganhando feições de credo. $\mathrm{O}$ "único problema" mencionado por Bobbio, nesse passo, mostra-se abissal. Não obstante, para o autor, "a ideia de que o socialismo não seja a antítese do liberalismo, mas seja de certo modo sua continuação e o seu complemento, é o principal ponto de vista a partir do qual se coloca o socialismo liberal italiano" (BOBBIO, 2000, p. 362). Cuida-se, pois, de uma via para se tentar a conjugação das correntes opostas, mas deixa sempre no ar o maior obstáculo, qual seja, a medida da cedência entre liberdade e igualdade. Miguel Reale, ao discorrer sobre o tema, conclui:

Nenhuma teoria como a do social-liberalismo, que está na base da Carta Magna vigente, reflete o fenômeno da inegável convergência das ideologias, que devemos respeitar, ficando a salvo, porém, o princípio fundamental da liberdade individual e de seus dois corolários essenciais: a livre iniciativa, no domínio econômico; e a autonomia da vontade na ordem jurídica (REALE, 2005, p. 60).

A equação desafia uma postura de estadista dos protagonistas, muito distante da política doméstica, oportunista, imediatista, sem espaço para os populistas de plantão, ancorados, não raro, em um maniqueísmo irracional.

\subsection{A intervenção do Estado na vida privada e social}

Não há negar-se que o tema ora em evidência decorre do anterior, pois o Liberalismo clássico via o Estado como um mal necessário (laissez-faire), ao passo que o socialismo nele se fundamenta. Esse conflito ideológico, que se diluiu no tempo em favor de uma política de resultados, está evidenciado na atualidade quando vem à baila o tema privatização versus estatização. Mas nem assim o resultado se consolida em fundamentos. Pragmatismo e viabilidade são os argumentos da resposta estatal, independentemente do que preconiza a matiz ideológica do Partido Político que forma a maioria na titularidade do Poder.

Malgrado a intervenção estatal chame esses paradigmas, daí a citação, a explanação sobre o tema foi dada de forma simples e direta (e essa foi sua intenção exteriorizada no 
prefácio) pelo saudoso Celso Bastos (1995), na obra Curso de Teoria do Estado e Ciência Política, em suas primeiras edições - nesse arrazoado, o foco concentrou-se na terceira. $\mathrm{O}$ autor confere a classificação do Estado segundo o seu grau de penetração na vida social e individual. Parte de três modelos abstratos: Estado Totalitário, Estado Liberal e Estado Social. Pode-se sintetizá-la imaginando-se uma linha progressiva de intervenção estatal, que parte de seu grau mínimo, o Estado Liberal, até atingir o seu grau máximo, o Estado Totalitário. No meio desse caminho estará o Estado Social, mais próximo de um ou de outro de acordo com o grau de intervenção autorizada. Não lhe é dado uma posição fixa nesta régua, pois quase sempre as opções políticas irão pendular.

Conforme Bastos (1995), no Estado Liberal, “o seu pressuposto fundamental é que o máximo de bem-estar comum é atingido em todos os campos com a menor presença possível do Estado". Seu destaque está no campo econômico, que rechaça a interferência estatal até mesmo como instrumento regulador. Conhecido pela lei econômica de mercado da "oferta e da procura". Mantem-se distante dos outros campos sociais, a conferir, por exemplo, liberdade religiosa e outros direitos civis (informação, reunião, etc.). A história demonstrou que não vingou na forma pura, por ser incapaz de encampar os direitos ditos de segunda dimensão, que dão o caráter substantivo do princípio da igualdade.

$\mathrm{Na}$ outra extremidade, posta-se o Estado Totalitário, que, segundo Celso Bastos (1995), “caracteriza-se por absorver no seu seio todas as manifestações da vida social e, até mesmo, individual. Nada lhe é estranho. Em tudo se imiscui”. E arremata:

Desde o poder político até o econômico e o social, passando pelo exercício das profissões, pela adoção da religião, pelo desenvolvimento cultural e artístico, pela vida familiar, pela organização do laser do indivíduo e dos seus gostos e preferências em matéria de moda, nada refoge à sua competência. [...] É um dos extremos a que o Estado pode chegar em matéria do exercício do poder (BASTOS, 1995, p. 66).

Faz-se, ainda, importante distinção entre Estado Totalitário e Estado Autoritário, deixando-se claro que esse representa um desvio do poder político exercido "por uma minoria contra a vontade da maioria” (BASTOS, 1995). Malgrado tal consideração, urge pontuar que, dificilmente, um Estado Totalitário (não patológico) não vá se inclinar, com o tempo, para a forma Autoritária, por desvio de sua finalidade natural, perseguir o Bem Comum, em favor da manutenção daqueles que se encontram extasiados na titularidade do poder, extremamente concentrado, sem qualquer ânimo de dele se apear. As ditaturas só se encerram mediante 
violência ou por degeneração ou, ainda, pela conjugação de ambos - fenômenos sempre dolorosos para o povo. Porém, normalmente são estabelecidos através de um discurso sedutor.

No meio termo, surge o Estado Social. As definições políticas estabelecerão o seu nível de intervenção. Geralmente, bem acentuado no âmbito econômico, que carrega, por sua vez, o universo político. Passa o Estado a regulamentar a economia, depois a fomentá-la, ainda insatisfeito, resolve explorar diretamente seguimentos antes próprios do âmbito privado. $\mathrm{O}$ Estado passa a ser um provedor, sem sufocar a iniciativa privada ou o direito de propriedade, inclusive aquele sobre os bens de produção. Mas se faz presente, com maior ou menor intensidade.

Interessante a (antiga e profética) observação de Dallari acerca de uma nova via de intervenção no âmbito social:

\footnotetext{
Desapareceram os limites entre o público e o privado, e o Estado, antigo mal necessário, passou a condição de financiador, sócio e consumidor altamente apreciado, tendo cada vez mais estimulada sua atitude intervencionista, justamente pelos grupos que mais se opunham a ela (DALLARI, 1995, p. 238).
}

A notória investigação denominada lava jato desvelou esta face de intervenção estatal com muita clareza, na qual grandes grupos econômicos colhiam elevados empréstimos do Estado, via bancos públicos, e não raro a origem do dinheiro era o próprio Tesouro, muitas vezes tornando-se sócios desse braço estatal, com titularidade de ações em novas empresas, e, ao mesmo tempo, fazendo do Estado o seu grande consumidor, com, por exemplo, as grandes obras - único ente capaz de ter poupança para financiá-las (hidroelétrica, rodovias, aeroportos, etc.). Infelizmente, a citada operação policial desvelou, também, um processo à margem da ordem jurídica, para dizer o mínimo.

De qualquer modo, é o Estado Social o modelo capaz de dar seguimento à nossa Carta compromissória, abrindo-se a possibilidade de se resolver a equalização das ideologias antagônicas, liberalismo (capitalista) e socialismo, pacificando-se as tensões entre o capital e o trabalho, a liberdade e a igualdade, a privatização e a estatização. Difícil, entretanto, será a definição da intensidade dessa intervenção, de modo a viabilizar um produto sincrético.

Aliás, aqui reside o primeiro passo para definição da dose tributária. O Estado que intervém é o Estado que despende de numerários, provenientes, no mais das vezes, da arrecadação tributária. Quando a intervenção se dá através do Poder de Império, o gasto estatal 
se resume à burocracia. É como se dá, por exemplo, com a atuação do Poder Judiciário: uma atividade substitutiva. É dizer, o Estado-Juiz substitui a vontade das partes e determinada que uma delas (sucumbente) faça algo em favor de outra. A realização material e, portanto, o ônus não parte do Estado, mas da parte vencida ${ }^{7}$. Entretanto, quando a intervenção desafia uma ação ex officio, como se dá com o Poder Executivo (infraestrutura, hospitais, segurança, escolas, planos sociais, etc.), então o dispêndio cresce geometricamente. Algumas atividades são essenciais, de sorte que a sua realização se dá de forma direta, sem margem de delegação. É o caso da segurança pública. Outras, pode o Estado optar por desenvolvê-las diretamente ou por empresas públicas, concessões, etc.

\subsection{O tamanho do Estado}

É imperioso, portanto, nesse passo, a definição do tamanho do Estado. Qual o tamanho da despesa que se pretende assumir. E este é um cálculo que deve levar em consideração a dívida consolidada (o resgate de títulos da dívida, a liquidação dos precatórios, etc.), os custos dos serviços públicos, entre despesas correntes (serviços prestados à sociedade) e as despesas de capital (os investimentos). A nomeação de um servidor, por exemplo, gera uma dívida sucessiva aos cofres públicos que pode beirar mais de sessenta anos, computados, os vencimentos, quando na ativa, os proventos, ao se aposentar, e eventuais pensões (viúva, etc.), vertentes do mesmo vínculo inaugural ${ }^{8}$.

Há outro assunto que deve ser levado em conta: a avaliação crítica acerca da origem das despesas públicas. Com muita propriedade, explica Harada:

O volume das despesas públicas, em última análise, resulta sempre de uma decisão
política, porque a formulação do elenco de necessidades de uma sociedade, a serem
satisfeitas pelo serviço público, é matéria que se insere no âmbito de atuação do poder
político. A este cabe a formulação da Política Governamental, na qual está prevista a
realização dos objetivos nacionais imediatos, objetivos esses eleitos em conformidade
com as ideias políticas, religiosas, sociais, filosóficas do momento, a fim de que o
plano de ação governamental tenha legitimidade perante a sociedade. Daí por que, ao
contrário do que ocorre no setor privado, onde os objetivos são adequados aos recursos

\footnotetext{
${ }^{7}$ Impõe-se uma observação: as dívidas rotuladas de "precatórios" não são dívidas vertentes do Poder Judiciário, mas sim da responsabilidade do Poder Executivo de responder pelas condenações judiciais que suporta, por descumprimento da lei, dos contratos e por atos ilícitos. É a fórmula constitucional prevista (CF, art. 100 e segs.) para dar execução às obrigações de dar quantia certa à parte exitosa em uma ação judicial em que a Fazenda sucumbiu. Não honrar os precatórios judiciais representa moratória silenciosa.

8 Segundo o site oficial Portal Brasil, o país tem 2.039.499 servidores públicos federais. (In www.brasil.gov.br/governo/2010/10/brasil-tem-mais-de-2-milhoes-de-servidores-publicos, atualizado em 28/07/2014, 12h28. Acesso em 26.7.17, às 02h37).
} 
econômico-financeiros existentes, no setor público, primeiramente, elegem-se as prioridades da ação governamental para depois, estudar os meios de obtenção de recursos financeiros necessários ao atingimento das metas politicamente estabelecidas (2011, p. p. 21-22).

De ver-se que o Estado está habituado, por assim dizer, a fixar suas despesas e, posteriormente, buscar as receitas que lhe darão o necessário suporte. Isto, por si só, já leva a uma situação conflitante, pois resta evidente que o anseio por melhorias é uma manifestação humana inata, mesmo por aqueles já satisfeitos. É infinita. Mas se é fácil estabelecer despesas, buscar as receitas é uma tarefa diametralmente oposta. Acrescenta-se que se cuida de uma decisão necessariamente política, formada por titulares que alçaram ao poder sempre com as promessas de mais e mais de tudo. Legítimas ou não, a equalização desses institutos contábeis torna-se trabalho de Sísifo ${ }^{9}$, gerando sempre um orçamento deficitário e fazendo com que o Estado saia a busca de novas receitas, quase sempre desaguando na elevação da carga tributária.

A Constituição até tem alguns mecanismos equalizadores. Por exemplo, a regra da

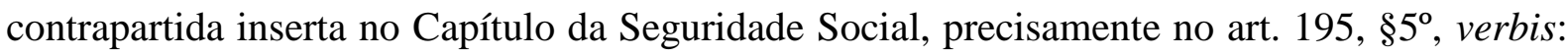
Nenhum benefício ou serviço da seguridade social poderá ser criado, majorado ou estendido sem a correspondente fonte de custeio total. Cuida-se de um instituto cujo escopo é a preservação do equilíbrio econômico-financeiro e atuarial do sistema. Note-se que o dispositivo ora em destaque faz parte de um sistema eternamente sob reformas e sempre pela mesma razão: descontrole orçamentário, entenda-se, as despesas superando as receitas. De qualquer modo, urge implementar outros mecanismos de igual natureza, de sorte a trazer o Poder Público à realidade de sua suficiência.

Daí, aliás, a importância da Lei de Responsabilidade Fiscal e seus instrumentos garantidores: o Controle Interno e o Controle Externo, realizado pelas Cortes de Contas, a Lei Penal, a Lei de Improbidade Administrativa, a Ação Popular, a Ação Civil Pública, o Impeachment, a Ação Direta Interventiva. E mesmo este denso aparato jurídico tem se apresentado, entre nós, insuficiente.

Mas não é só. Longe disso. José Marques Domingues de Oliveira pontua:

\footnotetext{
9 “... uma personagem da mitologia grega, condenado a repetir sempre a mesma tarefa de empurrar uma pedra até o topo de uma montanha, sendo que, toda vez que estava quase alcançando o topo, a pedra rolava novamente montanha abaixo até o ponto de partida por meio de uma força irresistível, invalidando completamente o duro esforço despendido" (in Wikipédia, a enciclopédia livre. https://pt.wikipedia.org/wiki/O_Mito_de_S\%C3\%ADsifo. Acesso em 26.7.2017, às 22h05).
} 
As políticas públicas são geralmente projetadas em plataformas eleitorais, chanceladas nas eleições se depois amadurecidas pelos poderes políticos. Para serem implementadas, precisam, em regra, de aprovação legislativa abrangente da alocação de recursos orçamentários bastantes.

Há, todavia, políticas públicas que, por sua transcendência, se encontram preconizadas pela própria Constituição, com se dá nos casos dos pactos financeiros federativos e dos direitos sociais (2010, p. 152-153).

A nossa Constituição atual, de 1.988, é a melhor da história de nosso Estado. Infelizmente, pouco respeitada, quiçá mesmo mutilada com um cipoal de emendas oportunistas. Uma das críticas mais interessante é no sentido de que o político elabora seu plano de governo e quer, após, adaptar a Constituição naquilo em que não houver compatibilidade, o que exige mudanças. Deveria fazer exatamente o contrário: elaborar o plano de governo adaptado à Constituição, como o propósito de dar-lhe eficácia.

Não há como negar que o momento histórico sob o qual a Assembleia Nacional Constituinte se desenvolveu induzia os representantes a um resgate da cidadania, seja no campo político, seja no campo social. Isso, entretanto, levou a doção de uma postura um tanto quanto pródiga. Em vários campos, o próprio constituinte atribuiu ao Estado a consecução de prestações sociais, notadamente nas áreas mais sensíveis, como a saúde e previdência. Correto quanto à matéria, mas imprudente na extensão, ou melhor, na rigidez de como arquitetou os institutos. Conferiu-se direitos sem um levantamento dos recursos e das fontes de custeio, como sói acontecer na esfera política. Apenas para se ter uma ideia, segundo o Ministério da Saúde, $71 \%$ dos brasileiros dirigiram-se a estabelecimentos públicos de saúde ${ }^{10}$. Hoje, de acordo com o IBGE (Instituto Brasileiro de Geografia e Estatística), somos, oficialmente, 204.450.649 habitantes, com projeção de 207.785.614 ${ }^{11}$. Lado outro, a ordem jurídica prescreve que a saúde será universal, integral e gratuita (CF, art.196, caput; art. 198, II, e §1º; L. 8080/90, art. 43). Isso significa em números que o SUS (Sistema Único de Saúde) é responsável, no momento, pela saúde de mais do que o dobro de toda a população da França ou do Reino Unido. Mas o Estado há de estar ainda presente em vários outros segmentos, igualmente críticos, aliás. Sistema Penitenciário e Segurança Pública são exemplos de sua hercúlea tarefa, e, como os demais, à beira do colapso total.

\footnotetext{
${ }^{10}$ Segundo o site oficial Portal Brasil. (In www.brasil.gov.br/saude/2015/06/71-dos-brasileiros-tem-os-serviçospublicos-de-saude-como-referencia, atualizado em 02/06/2015, 15h40. Acesso em 27.7.17, às 23h55).

${ }^{11}$ www.ibge.gov.br/home. Acesso em 27.7.17, às $23 \mathrm{~h} 58$.
}

Rev. de Direito, Economia e Desenvolvimento Sustentável| e-ISSN: 2526-0057| Maranhão | v. 3 | n. 2 | p. 100 - 118 | Jul/Dez. 2017. 
Importa consignar ainda que, muito embora sem previsão expressa na nossa ordem jurídica, muitos preconizam a aplicação do princípio da vedação ou proibição do retrocesso, é dizer, uma vez alcançada a positivação de direitos sociais, não mais poderá haver qualquer forma de diminuição ou mesmo extinção daqueles direitos. Passa a compor o patrimônio do destinatário, um direito subjetivo oponível contra o Estado. Esta ideia deita raízes em outros institutos: o direito adquirido, o princípio da segurança jurídica e o princípio da confiança. $\mathrm{O}$ primeiro é, expressamente, cláusula pétrea (CF, art. 60, IV, c/c o art. $5^{\circ}$, inc. XXXVI), insuscetível de modificação. Os demais são desdobramentos do Estado de Direito, de sorte que sua existência coincidirá com a existência do próprio Estado sob a batuta da Constituição. No mais, a abstenção do Estado nesta esfera provavelmente afetará o próprio ideal de proteção de uma vida digna ${ }^{12}$.

Mas tal preceito, sem se questionar aqui sua nobreza, deságua, novamente, nos mais desagradáveis temas: fonte de custeio e orçamento viável. Nesse passo, com muita propriedade e isenção, Flávio Martins Alves Nunes Junior (2017), em obra de fôlego recentemente lançada, toca no ponto sensível: Como compatibilizar o princípio da proibição do retrocesso e as crises econômicas? E arremata de forma percuciente, demonstrando, inclusive, que o mais admirado jurista do tema, Joaquim José Gomes Canotilho, reviu sua preleção anterior:

No nosso entender, com drástica redução do orçamento, por conta da queda de arrecadação, é impossível manter o mesmo número de políticas públicas, com a mesma intensidade, com a mesma amplitude. Reduzindo-se a arrecadação, como manter o investimento no FIES, PROUNI, Bolsa Família e outros programas que atingiram seu ápice quando da pujança econômica? Como vimos anteriormente os direitos têm custos e eles são impactados pelo orçamento exequível. Dessa maneira, no nosso entender, o princípio da proibição de retrocesso deve ser revistado em tempos de crise. O próprio professor Canotilho, um dos maiores defensores desse princípio, profetizou: a proibição do retrocesso social nada pode fazer contra as recessões e crises econômicas (reversibilidade fática). Em texto posterior foi bem mais pessimista o mestre português: $O$ rígido princípio da 'não reversibilidade' ou,

\footnotetext{
12 "No que diz respeito sua fundamentação e justificação e fundamentação jurídico-constitucional, apresentadas aqui de modo sumário, a proibição do retrocesso social costuma ser vinculada também ao dever de realização progressiva dos direitos sociais, tal como previsto no art. 2. ${ }^{\circ}$ do Pacto Internacional de Direitos Econômicos, Sociais e Culturais de 1966, ratificado pelo Brasil. Além disso, a proibição do retrocesso social guarda relação com o princípio da segurança jurídica (consagrado, entre outros, no Preâmbulo da Constituição Federal e no caput dos arts. 5. $^{\circ}$ e $6^{\circ}$ ) e, assim, com os princípios do Estado democrático e social de Direito e da proteção da confiança, na medida em que tutela a proteção da confiança do indivíduo e da sociedade na ordem jurídica, e de modo especial na ordem constitucional, enquanto resguardo certa estabilidade e continuidade do Direito, notadamente quanto à preservação do núcleo essencial dos direitos sociais. Ao mesmo tempo, a proibição de medidas retrocessivas reconduz ao princípio da máxima eficácia e efetividade das normas definidoras de direitos e garantias fundamentais (art. 5. ${ }^{\circ}, \S .{ }^{\circ}$, da CF), assim como, numa perspectiva defensiva do princípio da dignidade da pessoa humana, objetiva impedir a afetação dos níveis de proteção já concretizados das normas de direitos sociais, sobretudo no que concerne às garantias mínima de existência digna" (in SARLET, Ingo Wolfgang; MARINONI, Luiz Guilherme; MITIDIERO, Daniel. Curso de direito constitucional. São Paulo: Revista dos Tribunais, 2012, p. 567-568).
} 
formulação marcadamente ideológica, o 'princípio da proibição da evolução reacionária' pressupunha um progresso, uma direção e uma meta emancipatória e unilateralmente definidas: aumento contínuo das prestações sociais. Deve relativizarse esse discurso que nós próprios enfatizamos noutros trabalhos. A dramática aceitação de 'menos trabalho e menos salário, mas trabalho e salário para todos, $\mathrm{o}$ desafio da bancarrota da previdência social, o desemprego duradouro, parecem apontar para a insustentabilidade do princípio da não reversibilidade social" (2017, p. 1069).

E mais adiante conclui:

Dessa maneira, as crises econômicas recentes decretaram, senão a morte, o enfraquecimento substancial da proibição do retrocesso. Enquanto em terras brasileiras ainda se prestigia o princípio, seja na doutrina, seja nas decisões judiciais, como se fosse tábua de salvação dos direitos sociais, na Europa, o cenário é bem diverso. "Paulo Otero alude à passagem da 'hipervalorização doutrinária à arqueologia argumentativa', no sentido de que o princípio da proibição do retrocesso tem se tornado, hoje, numa 'peça retórica de pura arqueologia jurídica'. Também em França, Dominique Chagnollaud entende que esse princípio está em vias de extinção, tendo perdido uma relevância significativa a partir do momento em que o Conselho Constitucional deixou de aplicar em termos absolutos e passou a ter um entendimento mais relativo do mesmo. (2017, p. 1069)

A par da lucidez em destaque, o tema revolve questões metajurídicas. Uma vez mais, a interpretação se dá através dos pontos de vista ideológicos, na qual a ideia nem sempre se encontra com o plano real, dificuldade já externada anteriormente. Tudo, entretanto, haverá de ser levado em conta: sem a previsão de gastos não é possível estabelecer a receita e identificar suas fontes.

\section{OS LIMITES DA ATUAÇÃO ESTATAL NO CAMPO TRIBUTÁRIO}

A base do Estado de Direito concentra-se na forma como o poder político se manifesta, sempre trilhado pela ordem jurídica, incluindo-se aí a forma de ascensão à titularidade do poder. A Constituição é seu epicentro. Nela estará, portanto, a resposta para todas as crises atuais e vindouras. Disso resulta que a Carta não é, e nunca foi, um problema ou o problema, como se profetiza por alguns aqui e alhures. A Carta é sempre a solução. Se há problema, ele se encontra no intérprete, não na Constituição. A convocação de uma nova constituinte em nada ajudaria nesse caso.

A ordem jurídica, com seu extenso rol de direitos e garantias, cumpre este papel como nunca dantes se verificou por aqui. Seu eixo passou a ser o homem, e não o Estado. Mas este precisa ser sustentado, com dito. A Constituição então cuidou de criar um subsistema constitucional: o tributário. Não cria tributos, papel conferido às normas infraconstitucionais, 
mas realiza a partição de competências tributárias e estabelece princípios de formação do tributo $(\mathrm{CF}$, art. 145) e de vedação à sua instituição (CF, art. 150) - aqui já se tem uma forma protetiva. Desses, dois princípios são de maior relevo para a presente proposta, quais seja: o do não confisco (CF, art. 150, inc. IV) e o da capacidade contributiva (CF, art. 145, §1. ${ }^{\circ}$ ). Servem de escudo contra voracidade estatal em busca de recursos, já que as definições de gastos passam, primeiro, por um processo eleitoral, com suas paixões, crenças e ideologias, e são, em seguida, filtradas pela técnica burocrática e legislativa, mas esse processo político se dá antes de uma análise efetiva de existência de provisão e fonte de custeio precisa. Assim, projetam-se os gastos e, depois, perseguem-se as receitas, que são sempre um prognóstico, anota-se. E o contribuinte é lembrado.

\subsection{O Princípio do Não Confisco}

A Constituição estabelece que:

\footnotetext{
Art. 150. Sem prejuízo de outras garantias asseguradas ao contribuinte, é vedado à União, aos Estados, ao Distrito Federal e aos Municípios:

IV- utilizar o tributo com efeito de confisco;
}

Malgrado seja uma garantia extremamente importante, pois visa garantir o cidadão dos desmandos estatais, há de se convir que, devido à vagueza, a redação do dispositivo ajuda muito pouco. Primeiro, porque não oferece uma grandeza, de sorte que se para alguns a carga de um tributo pode ser excessiva, para outros, não. Pior: uns e outros podem não ser os destinatários de exação aferida e, ao mesmo tempo, serem influentes na decisão política. Em segundo lugar, o preceito não faz menção se a análise há de ser isolada ou global, é dizer, pode o Estado impor alta carga tributária em diversas espécies, inviabilizando a vida do cidadão, mas, ainda sim, a carga individualizada não configure o confisco. Em terceiro lugar, não se excogitou em dimensão temporal, do modo que a exação em um período seja compatível, mas as sucessivas exações da mesma espécie culminem por inviabilizar a base econômica da qual é retirado.

Diz Luciano Amaro acerca da garantia:

Dessa forma, o problema está em saber até onde pode avançar o tributo sobre o patrimônio do indivíduo, sem configurar confisco, ou, considerada isoladamente certa situação, qual o limite máximo do ônus tributário que legitimamente sobre ela poderia impor-se (2011, p. 168). 
E conclui:

O princípio da vedação de tributo confiscatório não é um preceito matemático; é um critério informador atividade do legislador e é, além disso, preceito dirigido ao intérprete e ao julgador, que, à vista das características da situação concreta, verificarão se determinado tributo invade ou não o território do confisco. $(2011$, p. $168)$.

De ver-se, portanto, que se cuida de uma garantia de baixa densidade, que não confere a segurança jurídica esperada para o instituto, devido ao alto grau de abstração e generalidade. $\mathrm{Na}$ prática, está ao alvedrio do intérprete, que o coloca em risco, gerando o mesmo fenômeno que se sucede com o princípio implícito da proporcionalidade, o qual acabou se tornando um "coringa" de interpretação, muitas vezes sem sequer estar acompanhado de um substrato lógicoracional. Vale conferir, nesse passo, a preciosa advertência de Eros Roberto Grau ${ }^{13}$.

\subsection{O Princípio da Capacidade Contributiva}

Inegavelmente, uma exação que exceda a capacidade contributiva do contribuinte termina por incorrer em verdadeiro confisco. Ambas, portanto, estão associadas, malgrado diferentes.

O parágrafo primeiro do art. 145 da Constituição traz a seguinte redação:

Sempre que possível, os impostos terão o caráter pessoal e serão graduados segundo a capacidade econômica do contribuinte, facultando à administração tributária, especialmente para conferir efetividade a esses objetivos, identificar, respeitados os direitos individuais e nos termos da lei, o patrimônio, os rendimentos e as atividade econômicas do contribuinte.

Uma vez mais, faltou clareza no dispositivo. Primeiro, a expressão inaugural "sempre que possível” permite a não aplicação da garantia dependendo da intenção, boa ou má, do intérprete. Há muito a nossa jurisprudência tornou-se um tanto quanto volátil, não havendo, entre nós, uma cultura formada de respeito aos precedentes, mesmo com a renovação do CPC,

\footnotetext{
13 "Estranhas e sinuosas vias são trilhadas nessa quase inconsciente procura de ius onde não há senão lex. Uma delas se expressa na produção multiplicada de textos sobre conflitos entre princípios e entre valores, o que em geral faz prova de ignorância a respeito da distinção entre o deontológico e o teleológico.

Outra, na banalização dos 'princípios' (entre aspas) da proporcionalidade e da razoabilidade, em especial do primeiro, concebido como um princípio superior, aplicável a todo e qualquer caso concreto - o que conferiria ao Poder Judiciário a faculdade de 'corrigir' o legislador, invadindo competência deste.

$\mathrm{O}$ fato, no entanto, é que proporcionalidade e razoabilidade nem ao menos são princípios - porque não reproduzem suas características -, porém postulados normativos, regras de interpretação/aplicação do direito" (GRAU, Eros Roberto. Por que tenho medo dos juízes (a interpretação/aplicação do direito e os princípios). 6. Ed. São Paulo: Malheiro, 2014, p. 20).
} 
notadamente o seu artigo 927 (Lei 13.105 de março de 2015) ${ }^{14}$. Assim, esta garantia está a assegurar o contribuinte quando as características elementares do imposto assim o permitir. É sempre bom lembrar que as grandes causas que envolvem as pessoas de direito público interno trazem sempre como principal argumento (não jurídico), a dimensão do deficit que a decisão poderá gerar em caso de insucesso - é o caso, no momento, da correção do FGTS. Com efeito, por mais que se diga que se trata de um princípio, de sorte a lhe ser conferido o tom de maximização de eficácia ${ }^{15}$, estar-se-á sempre sob a sombra de uma interpretação inovadora.

Lado outro, a jurisprudência tem acolhido a dicotomia entre imposto pessoal e imposto real, afastando desse último a garantia assinalada. Impõe-se, também, perquirir a viabilidade de conferir caráter pessoal à tributação. Isto porque, prima facie, deveria ficar à mercê da tributação a receita disponível do indivíduo, satisfeitas, portanto, suas necessidades básicas. Todavia, não há como avaliar e mensurar as necessidades básicas, exceto por um mínimo que garanta uma existência mínima. Porém, aqui, as carências são tão profundas que os paradigmas acerca do que seria o mínimo não permitem o atingimento de uma solução razoável. Por exemplo, o mais importante paradigma: o salário mínimo, por definição constitucional, capaz de atender às suas necessidades vitais básica e às de sua família com moradia, alimentação, educação, saúde, lazer, vestuário, higiene, transporte e previdência social $\left(\mathrm{CF}\right.$, art. $7 .^{\circ}$, inc. IV). O valor do salário mínimo em vigor é de $\mathrm{R} \$ 937,00$, desde $1.1 .17^{16}$. Qualquer valor acima seria, portanto, tributável, pois atendida a capacidade contributiva subjetiva do contribuinte, na forma prescrita pela Constituição, referente ao trabalhador e à sua família, destaca-se. Ademais, conferir trato pessoal pela Administração Pública, ainda que o dispositivo constitucional o autorize, como de fato o fez, sempre leva a soluções conflitantes.

Mas o problema não termina aí. Em verdade, a tributação no Brasil é superlativa por razões que ultrapassam a fronteira do Direito. Aqui uma tributação hipotética de oitenta por

\footnotetext{
${ }^{14}$ Art. 927. Os juízes e os tribunais observarão:

I - as decisões do Supremo Tribunal Federal em controle concentrado de constitucionalidade;

II - os enunciados de súmula vinculante;

III - os acórdãos em incidente de assunção de competência ou de resolução de demandas repetitivas e em julgamento de recursos extraordinário e especial repetitivos;

IV - os enunciados das súmulas do Supremo Tribunal Federal em matéria constitucional e do Superior Tribunal de Justiça em matéria infraconstitucional;

$\mathrm{V}$ - a orientação do plenário ou do órgão especial aos quais estiverem vinculados.

${ }^{15}$ Cf. TIPKE, Klaus; YAMASHITA, Douglas. Justiça fiscal e princípio da capacidade contributiva. São Paulo: Malheiros, 2002 (justiça fiscal e o princípio da capacidade contributiva e eficácia do princípio da capacidade contributiva no brasil).

${ }^{16}$ In www.salariominimo.net.br. Acesso em 30.7.17, às 00h40).
} 
cento do salário inviabilizaria claramente a vida do trabalhador. De qualquer trabalhador. Mas isto devido ao fato de que ele não tem o esperado retorno (mínimo) do Poder Público. Quitados os impostos, ainda lhe resta assegurar a saúde (plano privado), a segurança (seguros, segurança, tecnologia etc.), a educação (instituição privada), o transporte (automóvel, lotação, Uber, etc.) e assim por diante. E, por óbvio, não dá para pagar “duas" vezes por tais prestações essenciais: uma para o setor público, os impostos, que, por definição não se sujeitam a qualquer ação da Administração ou contraprestação, outra no campo privado (satisfação das necessidades vitais não prestadas pelo Poder Público). Daí não fazer qualquer sentido as comparações numéricas com outros países, notadamente os Escandinavos, pelos quais, justificadamente, se tem predileção.

\section{CONSIDERAÇÕES FINAIS}

Buscou-se, neste artigo, construir um caminho para a fixação da dose tributária correta a ser definida pelo Poder Político. Com efeito, de início, precedeu-se ao alerta da necessidade de se reconhecer, sem verniz, o modelo capitalista de economia instituído no Brasil, respeitando-se os institutos da propriedade privada e da livre iniciativa. E isto de forma alguma significa que se estará deixando de forma livre e egoísta a força do capital, sabidamente capaz de construir com seu inegável talento e, também, de destruir, acaso atue sem os instrumentos de controles estatais (fiscal, repressiva e supletiva). O Banco Central é o melhor dos exemplos. Como disse o compositor, Caetano Veloso, na música Sampa, "Da força da grana que ergue e destrói coisas belas".

Na sequência, mostra-se imperioso uma definição mais precisa acerca da densidade de intervenção estatal sobre o indivíduo e a sociedade, bem como os meios de realiza-la. É dizer, em qual ponto entre o liberalismo e o totalitarismo, o Estado brasileiro pretende se fixar. Anotase: quão maior for a intervenção, maior será, por óbvio, o tamanho do Estado e, proporcionalmente, os recursos para sustentá-lo. De revés, menor será o espaço privado, a liberdade.

Os dois primeiros passos percorreram o campo das ideias. Já o terceiro desce ao plano real. Há de se identificar o tamanho do Poder Público, suas dívidas, suas despesas correntes e suas despesas de investimento, além de se fixar as prestações positivas que se pretende ver implementadas, com fixação temporal. É dizer: como se compõe a coluna das despesas. A tarefa 
não é simples dado o nosso gigantismo, o número de entidades que compõem a Administração indireta e, ainda, a adoção da forma federativa de Estado, como suas necessárias autonomias políticas. Não é por menos que a Administração direta a todo instante faz o censo de seus servidores da ativa, aposentados e pensionistas - essa necessidade evidencia a falta de controle.

Uma vez quantificada a despesa, urge proceder à identificação das fontes de receitas e suas capacidades econômicas, respeitados os direitos dos contribuintes de forma clara, racional. Só então se poderá falar em quantificação adequada e justa da carga tributária.

\section{REFERÊNCIAS}

AGRA, Walber de Moura. Curso de direitos constitucional. 8. Ed. Rio de Janeiro: Forense, 2011.

AMARO, Luciano. Direito tributário brasileiro. 17. Ed. São Paulo: Saraiva, 2011.

BASTOS, Celso Ribeiro. Curso de teoria do estado e ciência política. 3. Ed. São Paulo: Saraiva, 1995.

BOBBIO, Norberto; BOVERO, Michelangelo (org.); VERSIANI, Daniela Beccaccia (trad.). Teoria geral da política: a filosofia política e as lições dos clássicos. Rio de Janeiro: Campus, 2000.

BRASIL. Disponível em: <<www.brasil.gov.br/governo/2010/10/brasil-tem-mais-de-2milhoes-de-servidores-publicos $>$. Acesso em 26.7.17, às 02h37).

BRASIL. Disponível em: <www.brasil.gov.br/saude/2015/06/71-dos-brasileiros-tem-osserviços-publicos-de-saude-como-referencia>. Acesso em 27.7.17, às $23 \mathrm{~h} 55$.

CARVALHO, Olavo de. O mínimo que você precisa saber para não ser um idiota. 13. Ed. Rio de Janeiro: Record, 2004.

CUNHA JÚNIOR, Dirley da. Curso de direito constitucional. 5. ed. Ampl. e Atual. Salvador: Podium, 2011.

DALLARI, Dalmo de Abreu. Elementos de teoria geral do estado. 19. Ed. São Paulo: Saraiva, 1995.

GRAU, Eros Roberto. Por que tenho medo dos juízes (a interpretação/aplicação do direito e os princípios). 6. Ed. São Paulo: Malheiro, 2014.

HARADA, Kiyoshi. Direito financeiro e tributário. 20. Ed. São Paulo: Atlas, 2011.

IBGE. Disponível em: 〈wwww.ibge.gov.br/home>. Acesso em 27.7.17, às $23 \mathrm{~h} 58$.

Rev. de Direito, Economia e Desenvolvimento Sustentável| e-ISSN: 2526-0057| Maranhão | v. 3 | n. 2 | p. 100 - 118 | Jul/Dez. 
NUNES JUNIOR, Flávio Martins Alves. Curso de direito constitucional. 1. Ed. São Paulo: Revista dos Tribunais, 2017.

OLIVEIRA, José Marques Domingues de. Tributação, orçamento e políticas públicas. Revista bimestral de direito público - n.63, Forum - 2010.

PORTAL DA SAÚDE. Disponível em: <www.portaldasaúde.saude.gov.br/index.php/oministerio/principal/secretarias/sas/sas-noticiais/28256-sus-fila-única-para-cirurgias-eletivas> . Acesso em 10.7.2017, às 21h10.

REALE, Miguel. O estado democrático de direito e o conflito das ideologias. 3. Ed. rev. São Paulo: Saraiva, 2005.

SALÁRIO MÍNIMO. Disponível em: 〈www.salariominimo.net.br〉. Acesso em 30.7.17, às 00h40.

SARLET, Ingo Wolfgang; MARINONI, Luiz Guilherme; MITIDIERO, Daniel. Curso de direito constitucional. São Paulo: Revista dos Tribunais, 2012.

SCHOUERI, Luiz Eduardo. Direito tributário. 4. Ed. São Paulo: Saraiva, 2015.

TIPKE, Klaus; YAMASHITA, Douglas. Justiça fiscal e princípio da capacidade contributiva. São Paulo: Malheiros

WIKIPEDIA. Disponível em: 〈https://pt.wikipedia.org/wiki/O_Mito_de_S\%C3\%ADsifo>. Acesso em 26.7.2017, às 22h05. 